\title{
The Effects of Ram Exposure, Progestogen and eCG on Reproductive Performance of Fat Tail Ewes in Non- Breeding Season
}

\author{
Massoud - Talebkhan Garoussi ( $\nabla$ garoussi@ut.ac.ir) \\ University of Tehran Faculty of Veterinary Medicine \\ Omid Mavadati \\ University of Tehran Faculty of Veterinary Medicine \\ Mohammad Ali Bahonar \\ University of Tehran Faculty of Veterinary Medicine \\ Mehran Dabiri \\ University of Tehran Faculty of Veterinary Medicine
}

\section{Research Article}

Keywords: Reproductive performance, ewe, eCG, progestogen, ram exposure, Shaal

Posted Date: November 30th, 2021

DOl: https://doi.org/10.21203/rs.3.rs-1082913/v1

License: (a) (1) This work is licensed under a Creative Commons Attribution 4.0 International License. Read Full License 


\section{Abstract}

Sheep are considered short-day breeders. Exposure of rams to anestrus ewes results in an increase in LH secretion. The aims of this study was to determine whether the presence and exposure of rams can effect on reproductive performance such as: pregnancy rate, litter size, sex of lamb, fecundity rate and prolificacy rate of fat tail Iranian Shaal breed ewes in non-breeding season using progesterone (p4) analogue with or without equine chorionic gonadotropin (eCG). Totally, 100 ewes out of 138 non-cyclic ewes with $<0.5 \mathrm{ng} / \mathrm{ml} \mathrm{P4}$ were selected for this study. They were aged 2 to $>7$ years old. They were stratified to two groups (control and treatment). The ewes in treatment and control groups received 13 days a sponge containing $60 \mathrm{mg}$ medroxyprogesterone acetate (MPA). The treatment group consists of 3 subgroups and each group contains 25 ewes equally. They were included: 1- P4, eCG and Ram exposure. 2- P4 and ram exposure. 3- P4 and eCG. Ewes in control group received only P4. The ewes were located in isolated corrals for 40 days. The ram to ewe ratio was 1 to 5 . Twenty healthy rams were housed in an isolated pen from ewes with distance 1500 m during 40 days. Rams exposed three days before sponge withdraw (day 10). They were separated by considerable distance (2 meters) using fence. The related groups received 500 IU eCG on the day of sponge removal (day 13). The rams were released into the ewe flock after removing the sponge in treatment and control groups. Pregnancy diagnosis performed using transabdominal ultrasonography. The obtained data analyzed using SPSS version 16. The conception rate in treatment and control groups were differed significantly $(P<0.01)$. The conception rate in P4+ram exposure+ eCG, P4+ramexposure and P4+ eCG were 96\%(no.24), 80\%(no.20) and 88\% (no.22), respectively. However, the conception rate in control group was $60 \%$ (no. 15). The fecundity rates were $136 \%$, $100 \%$ and $124 \%$ in treatment subgroups, however, it was $84 \%$ in control group, respectively. There were no significant differences among genus and weight of lambs in treatments subgroups and control group $(P>0.05)$.

It is concluded that ram exposure can increase significantly reproductive performance in non-breeding season fat tailed ewes Shaal breed.

\section{Introduction}

Sheep are seasonally polyestrous, short-day breeders, cycling in late summer and early autumn, resulting in spring lambing (Shinomiya et al., 2014). Sheep are considered short-day breeders because their breeding season is regulated by the length of the day or, more specifically, by the increased duration of night which is the main environmental factor responsible for the seasonality of reproduction in sexual activity.

Seasonal breeding in sheep is a problem for the sheep industry. Although the gestation length of the ewe averages only $148 \mathrm{~d}$, the most ewes are not able to have cycle in spring. Therefore, it is a natural limitation for producer to have only one lamb crop per year.

The stimulus for the annual onset of sexual activity is declining length of daylight. The out of breeding season sexual activity onset can be advanced by artificial manipulation using hormonal agents. Exogenous progesterone may be used in anestrous ewe to induce estrus in non-breeding season. It is given continually over a period of time similar to the normal luteal phase, thus mimicking the luteal phase and prime the brain for cycling, allowing for behavioral estrus after withdrawal and the events of a normal follicular phase will be stimulated (Catalina Cabrera et al., 2019. Noaks et al., 2019). Progesterone analogues or progestogens(P4) are marketed as sponges, vaginal devices or as implant (Garoussi et al., 2019, Talebkhan Garoussi and Golzar., 2005). The combination of equine chorionic gonadotropin (eCG), formerly pregnant mare serum gonadotropin (PMSG) with progestogens priming is a popular option for small ruminants to enhance follicular growth and ovulation (Joaquim de Sousa Lima et al., 2021. Garoussi et al., 2019. Ozyurtlu et al., 2010. Windorski et al., 2008). 
The response of isolated anestrous ewes to the exposure of rams has been known for many years. This response is characterized by an increase in luteinizing hormone ( $\mathrm{LH}$ ) pulse frequency and a decrease in the negative feedback of estradiol- $17 \beta$ on the hypothalamic-pituitary axis culminating in an LH surge (approximately $30 \mathrm{~h}$ after ram releasing) that is followed by a ovulation (Noaks et al. 2019. Youngquist and Threlfall 2007. Martin et al. 1986 Martin et al., 1980). The resulting corpus luteum (CL) has either a normal or a short life span (Martin et al. 1986). Most ewes with a normal life span CL following their first ovulation display estrus prior to their second ovulation. Exposure of anestrous ewes to rams has also been shown to increase the number and diameter of ovarian follicles (Atkinson and Williamson, 1985). It is shown that ewes which run continually with rams are more fertile than ewes that are kept isolated from rams (Abecia et al., 2015, Nugent et al., 1988).

Ram exposure allows rams to have visual, olfactory, auditory without any tactile contact with ewes. Ewes do not require direct physical contact with rams in order to be stimulated to ovulate. Rams produce chemical substances called pheromones, which are perceived by the ewe and can stimulate the onset of estrus ewes. For the ram exposure to work, ewes should be isolated from rams for at least 6 weeks. Ewes must have no contact with rams by either sight, sound, or smell, which means that they must be separated by considerable distance. The great value of the ram exposure is synchronization of estrus activity (Abecia et al., 2015. Hawken et al., 2005).

In out of breeding season anestrous ewes, the exposure of males triggers an increase in the frequency of ovulation (Delgadillo et al., 2009). This increase stimulates follicular development and is followed by a preovulatory surge of LH. Consequently, a high percentage of females exposed to rams ovulate within the first 3-4 days after the stimulus (Martin et al., 1986). However, this ovulation is not accompanied by estrous behavior unless ewes are primed with progestagens (Hunter and Einer-Jensen.,2005). During the non-breeding season, progestagen priming may be used for a period of time (9-14 days), followed by the administration of equine chorionic gonadotrophin (eCG) (Garoussi et al., 2019. Garoussi et al., 2012. Ungerfeld and Rubianes, 1999.) or the introduction of rams (Ungerfeld et al., 2003).

The objective of this study was to determine whether the presence and exposure of sexually active rams can effect on reproductive performance such as: pregnancy rate, litter size, sex of lamb, fecundity rate and prolificacy rate fertility, fecundity of Shaal breed ewes in non-breeding season using progesterone analogue with or without eCG.

\section{Materials And Methods}

\section{Study location}

The experiment was performed in May-July (the nonbreeding season) under the influence of natural lighting in the suburb of Tehran-Iran (the capital). This experiment was done in Amin Abad research farm, Faculty of Veterinary Medicine, University of Tehran-Iran which is located $30 \mathrm{~km}$ south-east of Tehran. The latitude, longitude, and altitude are $35.467,51.250$, and $1189 \mathrm{~m}$, respectively. The agro-ecology of the region is semi-arid with the average $229.9 \mathrm{~mm}$ (9.1 in) of rainfall per year and the yearly average temperature in the region is $30^{\circ} \mathrm{C}\left(86^{\circ} \mathrm{F}\right)$.

\section{Animals}

Shaal breed sheep is a local breed from shaal area in Ghazvin Province-Iran whose characteristics have been described (Akbarinehad et al., 2014). Rams used in this experiment were of the same breed.

In total, 100 out of 138 non-pregnant, non-lactating, fat-tailed Shaal breed ewes almost 2 to 7 years old were selected for out of breeding season program. The weight of the ewes ranged $50-60 \mathrm{Kg}$. Body condition scoring (BCS) of the ewes were evaluated using palpation of the back (1-5 points) (Kenyon et al. 2014). The selected ewes were located in 
isolated corrals under strict sanitary programs and dietary measures including hay, corn silage, straw and concentrate with trace elements and minerals. For internal and external parasites, anitparasitic medication was described. Clean and hygienic water were accessible for them.

Twenty healthy rams were selected for breeding. They were housed in an isolated pen from ewes with distance 1500 $\mathrm{m}$ during 40 days before the initiation of the experiments not to see, hear the sounds and smell of the ewes.

Three experiments were conducted to examine the effects of ram exposure during the non-breeding season, in combination with Progestogen (Medroxyprogesterone acetate) (MPA) intravaginal sponge treatment consist of 60 mg MPA with or without eCG on estrus synchronization, reproduction performance, such as: pregnancy rate, litter size, sex of lamb, fecundity rate and prolificacy rate (Youngquist and Threlfall 2007).

They were included 2 groups: treatment and control. All of the ewes in both groups received 13 days of $\mathrm{P}_{4^{-}}$ impregnated intravaginal sponges (Gonaser, Hipra, Spain). However, ewes in treatment group divided to 3 subgroups included: 1- P4, eCG and Ram exposure (no.25). 2- P4 and ram exposure (no.25). 3- P4 and eCG (no.25). Ewes in control group received only P4 (no.25).

Ewes had no direct contact with rams for ram exposure. They were separated by considerable distance (2 meters) using fence. Rams exposed to related ewes 3 days before sponge withdrawal (day 10). Rams removed at sponge withdrawal. At sponge withdrawal ewes in related treatment subgroups received $500 \mathrm{IU}$ eCG. The rams were released into the ewe flock after removing the sponge and eCG injection (Fig 1).

\section{Hormonal assays}

\section{Progesterone assay}

In order to make sure that 100 out of 138 ewes were in seasonal anestrus (blood P4 < 0/5 ng/ml) (Noaks et al. 2019), approximately $10 \mathrm{ml}$ two blood samples from jugular vein were collected 10 days apart for serum progesterone analysis. The samples were drawn into $10 \mathrm{ml}$ sterile collecting tubes and sent to the laboratory for analysis. The collected samples were centrifuged at $3000 \times \mathrm{g}$ for $20 \mathrm{~min}$. The extracted serum poured into a 2-ml Eppendorf tubes and the number of each ewe was written on the tubes. They were stored at $-21^{\circ} \mathrm{C}$ until the P4 analysis. The P4 level was assayed using ELISA kit (DRG Instruments $\mathrm{GmbH}$, Germany). Ewes (no. 38) with the P4 level >0/5 ng/ml were eliminated from the experiment.

\section{Statistical analysis}

Data were analyzed at $\mathrm{P} \leq 0.05$ using the SPSS statistical software (Version 25 SPSS Inc, Chicago, Illinois).

\section{Results}

Ewes exposed to the rams and used eCG exhibited a higher proportion of pregnancy rate throughout the experiment than the ewes in control group $(\mathrm{P}<0.05)$ (Table 1). The pregnancy rate in $\mathrm{P} 4$, ram exposure $(\mathrm{RE})+\mathrm{eCG}$ and $\mathrm{P} 4+\mathrm{eCG}$ were $96 \%$ and $88 \%$, respectively. However, there were no significant differences in treatment ewes without eCG in comparison with control group ( $P>0.05$ ) (Table 1). The exact $P$-values were 0.002 and 0.02 for the above mentioned groups, respectively. 
Table 1

The effect of ram exposure, eCG and Progestogen on conception rate in nonbreeding season in fat tail shaal breed ewes.

\begin{tabular}{|c|c|c|c|c|}
\hline \multirow[t]{2}{*}{ Groups } & \multicolumn{2}{|c|}{ Pregnancy rate } & \multirow[t]{2}{*}{ Total } & \multirow[t]{2}{*}{ P-Value } \\
\hline & $+(\%)$ & $-(\%)$ & & \\
\hline Control (P4) & $15(60)^{a}$ & $10(40)^{a}$ & 25 & \\
\hline \multicolumn{5}{|l|}{ Treatment } \\
\hline$P 4,+R E+e C G$ & $24(96)^{b}$ & $1(4)^{b}$ & 25 & 0.002 \\
\hline P4+RE & $20(80)$ & $5(20)$ & 25 & 0.12 \\
\hline $\mathrm{P} 4+\mathrm{eCG}$ & $22(88)^{c}$ & $3(12)^{c}$ & 25 & 0.02 \\
\hline Total & $81(81)$ & 19(19) & 100 & \\
\hline
\end{tabular}

RE: Ram Exposure

eCG: Equine Chronic Gonadotropin

P4: Progesterone analogue

Table 2 showed the reproductive performance of the ewes in ram exposure programming with or without eCG in nonbreeding season in fat tail Shaal ewes. There were no significant differences between single or twin lambing in treatment and control groups ( $P>0.05)$. The fecundity rate increased in treatments group in comparison with control group. They were $136 \%, 100 \%$ and $124 \%$ in treatment subgroups, however, it was $84 \%$ in control group, respectively. The prolificacy rates are shown in table 2.

Table 2. Reproductive performance in ram exposure, P4 analogues, with or without eCG program in non-breeding season fat tail Shaal breed. 


\begin{tabular}{|c|c|c|c|c|c|c|c|}
\hline \multirow[t]{2}{*}{ Groups } & \multicolumn{2}{|c|}{ Lambing } & \multirow{2}{*}{$\begin{array}{l}\text { Total } \\
\text { (\%) }\end{array}$} & \multirow{2}{*}{$\begin{array}{l}\text { P- } \\
\text { Value }\end{array}$} & \multirow{2}{*}{$\begin{array}{l}\text { Lambing rate } \\
(\%)\end{array}$} & \multirow{2}{*}{$\begin{array}{l}\text { Fecundity rate } \\
\text { (\%) }\end{array}$} & \multirow{2}{*}{$\begin{array}{l}\text { Prolificacy rate } \\
\text { (\%) }\end{array}$} \\
\hline & $\begin{array}{l}\text { Single } \\
(\%)\end{array}$ & $\begin{array}{l}\text { Twin } \\
\text { (\%) }\end{array}$ & & & & & \\
\hline \multirow[t]{2}{*}{ Control (P4) } & 9 & 6 & 15 & & 60 & 84 & 1.4 \\
\hline & (11.11) & (7.4) & (18.51) & & & & \\
\hline \multicolumn{8}{|l|}{ Treatments } \\
\hline \multirow[t]{2}{*}{$P 4+R E+e C G$} & 14 & 10 & 24 & 0.92 & 96 & 136 & 1.42 \\
\hline & (17.28) & (12.34) & (29.62) & & & & \\
\hline \multirow[t]{2}{*}{ P4+ RE } & 15 & 5 & 20 & 0.34 & 80 & 100 & 1.25 \\
\hline & (18.51) & (6.17) & (24.69) & & & & \\
\hline \multirow[t]{2}{*}{ P4+ eCG } & 13 & 9 & 22 & 0.96 & 88 & 124 & 1.4 \\
\hline & (16.04) & $(11.11)$ & $(27.16)$ & & & & \\
\hline \multirow[t]{2}{*}{ Total } & 51 & 30 & 81 & 0.83 & & & \\
\hline & (62.96) & (37.03) & & & & & \\
\hline
\end{tabular}

Table 3 shows the distribution of genus of lambs and birth weight of the lambs in out of breeding season in ram exposure programing with or without eCG. There were no significant differences among lamb genus in treatments and control groups $(P>0.05)$. The weight of male lambs averaged greater than female lambs. However, they did not differ significantly in treatments and control groups $(P>0.05)$.

Table 3: Distribution of lambs genus and average birth weight in nonbreeding season program using ram exposure, P4 analogues with or without eCG in fat tail Shaal breed. 


\begin{tabular}{|c|c|c|c|c|c|c|c|c|c|c|c|c|}
\hline \multirow[t]{4}{*}{ Groups } & \multicolumn{5}{|c|}{ Lamb Genus } & \multirow{4}{*}{$\begin{array}{l}\text { Total } \\
\text { (\%) }\end{array}$} & \multicolumn{6}{|c|}{ Weight (Kg) } \\
\hline & \multicolumn{2}{|c|}{ Single } & \multicolumn{3}{|l|}{ Twin } & & \multicolumn{2}{|c|}{ Single } & \multicolumn{4}{|c|}{ Twin } \\
\hline & [ & प & 吅 & 吅 & 吅 & & प & प & 吅 & 吅 & 吅 & \\
\hline & (\%) & (\%) & (\%) & (\%) & (\%) & & & & & & & \\
\hline ૧ & [ & & & & & & & & & & & \\
\hline \multirow[t]{2}{*}{ Control (P4) } & 4 & 5 & 1 & 1 & 4 & 21 & 5.02 & 5.22 & 4.4 & 4.25 & 4.37 & 3.7 \\
\hline & 3.6 & 4.5 & 0.9 & 0.9 & 3.6 & 18.91 & & & & & & \\
\hline \multicolumn{13}{|l|}{ Treatments } \\
\hline \multirow[t]{2}{*}{ P4+RE+eCG } & 8 & 6 & 3 & 3 & 4 & 34 & 4.24 & 5.08 & 3.97 & 4.55 & 4.77 & 4.57 \\
\hline & 7.2 & 5.4 & 2.7 & 2.7 & 3.6 & 30.63 & & & & & & \\
\hline \multirow[t]{2}{*}{$P 4+R E$} & 4 & 11 & 1 & 2 & 2 & 25 & 5.4 & 4.9 & 4.4 & 3.7 & 4.55 & 4.35 \\
\hline & 3.6 & 9.9 & 0.9 & 1.8 & 1.75 & 22.52 & & & & & & \\
\hline \multirow[t]{2}{*}{$\mathrm{P} 4+\mathrm{eCG}$} & 7 & 6 & 3 & 2 & 4 & 31 & 5.18 & 4.2 & 3.9 & 4.85 & 4.22 & 3.95 \\
\hline & 6.3 & 5.4 & 2.7 & 1.8 & 3.6 & 27.92 & & & & & & \\
\hline \multirow[t]{2}{*}{ Total } & 23 & 28 & 16 & 16 & 28 & 111 & & & & & & \\
\hline & 20.72 & 25.22 & 14.41 & 14.41 & 25.22 & & & & & & & \\
\hline
\end{tabular}

\section{Discussion}

There were significant differences in pregnancy rate among the ewes in control and treatment groups $(P<0.05)(T a b l e$ 1). The pregnancy rate was increased $(24 / 25,96 \%$ and $22 / 25,88 \%$ in treatment subgroups, respectively) in comparison with control group $(15 / 25,60 \%)$ using (MPA) alone. The different treatment subgroups received MPA with variable experiments. The pregnancy rates in ram MPA, eCG and ram exposure subgroup were the highest $(P=0.002)$. However, it was higher in MPA and eCG subgroup in comparison with control group $(P=0.02)$. But, there were no significant differences in MPA and ram exposure treatment subgroup in comparison with control group $(P>0.05)$ (Table 1). It showed that the genital system of ewes could be influenced by ram exposure and eCG in out of breeding season. In addition, twinning, lambing, fecundity and prolificacy rate increased in P4, eCG and ram exposure treatment subgroup in comparison with control group (Table 2). It is likely that the non-significant obtained results in table 2 might be due to the small size. 
Ram exposure results in increased LH production in receptive ewes, followed by ovulation within a few days. Administration of P4 prior to ram exposure may improve the synchrony of estrus. It is the best that the females be abruptly exposed to the male following isolation from the sight, sound and odor of rams for the 30 to 60 days prior to exposure. The ram need only be exposed for 48 hours to have full effect. For optimum response, ewes must be weaned prior to exposure and be in good breeding condition (Youngquist and Threlfall., 2007).

The male exposure stimuli to bypass the suppressive effect of progesterone was first showed in ewes treated with progesterone implants (Martin et al., 1983. Pearce and Oldham., 1983) or medroxyprogesterone acetate (Evans et al., 2004) where exposure of treated ewes to rams increased LH secretion. The effect of ram exposure stimuli on LH secretion is not limited to exogenous sources of progesterone and cyclic ewes at all stages of the oestrous cycle respond to rams with an increase in pulsatile LH secretion (Hawken et al., 2007). It was found that, ram exposure in Suffolk crossbred ewes during the last 3 days of exogenous P4 synchronisation, the LH surge, oestrus and ovulation all began earlier, whereas the duration of oestrus was reduced (Evans et al., 2004).

Management of the ovine oestrous cycle is mainly based on the use of exogenous hormones to mimic or enhance (progesterone and its analogues) the activity of the corpus luteum, combined with the application of other hormones mimicking the pituitary secretion of gonadotrophins (e.g. eCG) in non-breeding season ewes. However, in this study, the high pregnancy rate on day 10 after ram exposure and eCG indicates that ovulation did occur in most ewes $(24 / 25,96 \%)(P=0.002)$. On the other side, the pregnancy rate was lower in $P 4+$ eCG treatment subgroup which did not expose to the rams $(22 / 25,88 \%)(P=0.02)$ (Table 1). Possible explanations for the reduction of pregnancy rate in P4-treated and eCG animals are alterations in final follicle growth (Gonzalez-Bulnes et al., 2005) and ovulation (Vinoles et al., 2001. Killianet al., 1985) as well as impairment of sperm transport and survival in the female genital system, reducing the number of fertilized ova (Allison and Robinson., 1970 Hawk and Conley 1972). MPA alone in control group is not highly efficacious in treating seasonal anoestrus ewes because some individual animals: (1) have not enough follicular activity at the beginning of treatment; (2) may ovulate spontaneously during treatment; and (3) have follicle growth but fail to ovulate after withdrawal of the progesterone.

In this study, lambing rates (80-96\%) and fecundity rate (100-136\%) were higher thancontrol group (60\% and $84 \%$, respectively). The main reason for the high prolificacy achieved even without eCG treatment was probably that this experiment was performed only well-managed and conditioned ewes.

In our study, we found no effect on single, twinning and lamb genus (Table 3). However, twinning rate was higher in treatment subgroups in comparison with control ewes.

\section{Conclusion}

This study reports that exposing Shaal breed ewes to ram for 3 days followed by eCG administration in progestogen programming was highly effective to induce fertile estrous activity during the nonbreeding season. When ram exposure used in out of breeding season with MPA and eCG, appear to be inferior to P4 + eCG or P4 ram exposure in ability to stimulate anovular ewes to cycle in out of breeding season. The male exposure has great potential for synchronizing oestrus in seasonal Shaal breed during non-breeding season. This leads us to consider new perspectives of research on the issue of isolation of females from males in non-breeding season programming.

\section{Declarations}

\section{Funding}


The authors would like to acknowledge the financial support of the University of Tehran for this research under grant number 28903.6.4.

Ethics approval: The entire experiment was performed in accordance with regulations by the ethical committee for animal welfare at Faculty of Veterinary Medicine, University of Tehran, Tehran-Iran.

Consent to participate: All the authors approved the final manuscript.

Consent for publication: All the authors consented the final manuscript.

Conflicts of interest: Authors have declared no conflict of interest.

Data availability: All data generated or analyzed during this study are included in this published article.

Code availability: All codes analyzed during this study are included in this published article.

\section{References}

1. Abecia J.A., Chemineau P., Flores J. A., Keller M., Duarte G., F. Forcada F., Delgadillo J.A. (2015). Continuous exposure to sexually active rams extends estrous activity in ewes in spring. Theriogenology. 84, 9, 15491555. doi.org/10.1016/j.theriogenology.2015.08.002

2. Akbarienejad V., Kazempoor R., Shohaei M., Mehrangiz R., Oji R. (2014). Atlas of Iranian sheep breeds. Noorbakhsh press, Tehran-Iran. 86-87.

3. Allison AJ, Robinson TJ. (1970). The effect of dose level of intravaginal progestagen on sperm transport, fertilization and lambing in the cyclic Merino ewe. J Reprod Fertil. 22:515-31.

4. Atkinson S. and Williamson P. (1985). Ram-induced growth of ovarian follicles and gonadotrophin inhibition in anoestrous ewes. Journal of reproduction and fertility. 73, 185-189.

5. Catalina Cabrera, Gabriele U. Maier, Matthew Cuneo, Bret R. McNabb. (2019). The use of progesterone intravaginal devices is superior to use of the ram effect at hastening the reproductive performance in transitional Targhee ewes. Theriogenology 128. 17. 22.

6. Delgadillo J. A., Gelez. H., Ungerfeld. R., Hawken A. R. P., Martin G. B. (2009). The 'male effect' in sheep and goats -Revisiting the dogmas. Behavioural Brain Research. 200. 304-314.

7. Evans AC, Duffy P, Crosby TF, Hawken PA, Boland MP, Beard AP. (2004). Effect of ram exposure at the end of progestagen treatment on estrus synchronization and fertility during the breeding season in ewes. Anim Reprod Sci. 84:349-58.

8. Garoussi M. T., Mavadati O., Bahonar M., Ragh M. J. (2019). The effect of medroxyprogesterone acetate with or without eCG. Tropical Animal Health and Production. 52, 1617-1622. https://doi.org/10.1007/s11250-01902159-8.

9. Gonzalez-Bulnes A, Veiga-Lopez A, Garcia P, Garcia-Garcia RM, Ariznavarreta C, Sánchez MA, et al. (2005). Effects of progestagens and prostaglandin analogues on ovarian function and embryo viability in sheep. Theriogenology. 63:2523-34.

10. Hawk HW, Conley HH. (1972). Investigation of sperm transport failures in ewes administered synthetic progestagen. J Anim Sci. 34: 609-13.

11. Hawken PAR, Beard AP, O'Meara CM, Duffy P, Quinn KM, Crosby TF, Boland MP, Evans ACO. (2005). The effects of ram exposure during progestogen oestrus synchronisation and time of ram introduction post progestagen 
withdrawal on fertility in ewes. Theriogenology. 2005. 63: 860-871.

DOI: https://doi.org/10.1016/j.theriogenology.2004.05.007

12. Hawken PAR, Beard AP, Esmaili T, Kadokawa H, Evans ACO, Blache D, G.B. Martin G. B. (2007). The introduction of rams induces an increase in pulsatile LH secretion in cyclic ewes during the breeding season. Theriogenology. 68:56-66. DOI:10.1016/j.theriogenology.2007.03.023

13. Hunter R. H. F and N. Einer-Jensen N. (2005). Pre-ovulatory temperature gradients within mammalian ovaries: a review. Journal of Animal Physiology and Animal Nutrition 89. 240-243. doi.org/10.1111/j.14390396.2005.00509.x

14. Joaquim de Sousa Lima., Márcio da Silva Costa., Júlio Rodrigues Pereira Júnior., Guilherme José Bolzani de Campos Ferreira., Luciana Rocha Faustino., Carlos Eduardo Fonseca Alves., Eunice Oba., Anna Clara Accioly Ferreira., José Ricardo de Figueiredo., Cleidson Manoel Gomes da Silva. (2021). Comparative analysis of the hormone production and gene expression profiles in ovine uterus tissue during oestrus cycle synchronized using medroxyprogesterone acetate plus eCG and prostaglandin analogue. Semina: Ciênc. Agrár. Londrina. 42, 6. 3321-3336. DOI: 10.5433/1679-0359.2021v42n6p3321

15. Kenyon, P.R., Maloney, S.K. and Blache, D. (2014). Review of sheep body condition score in relation to production characteristics. New Zealand Journal of Agricultural Research, 57(1), 38-

64. doi.org/10.1080/00288233.2013.857698

16. Killian DB, Kiesling DO, Warren JE. (1985). Lifespan of corpora lutea induced in estrous-synchronized cycling and anestrous ewes. J Anim Sci. 61:210-5.

17. Martin GB, Oldham CM, Lindsay DR. (1980). Increased plasma LH levels in seasonally anovular Merino ewes following the introduction of rams. Animal Reproduction Science. 3:125-32.

18. Martin GB, Oldham CM, Cognie Y, Pearce DT. (1986). The physiological response of anovulatory ewes to the introduction of rams-a review. Livestock Production Science.15:219-47.

19. Martin GB, Scaramuzzi RJ, Oldham CM, Lindsay DR. (1983). Effects of progesterone on the responses of Merino ewes to the introduction of rams during anoestrus. Aust J Biol Sci. 36:369-78.

20. Massoud Talebkhan Garoussi, Nima Farzaneh, Ehssan Gallehdar, Mehrdad Mohri. (2012). Reproductive performance in out-of-breeding season of fatty ewes using implant norgestomet with or without PMSG. Tropical Animal Health and Production. 44:965-968. doi.10.1007/s11250-011-9993-z

21. Noaks, D. E., Parkinson, T. J., England G. C. W. (2019). Veterinary reproduction and obstetrics. 10th edition. Saunders, Elsevier. UK. Pages:59-61.

22. Nugent R. A., Notter D. R., McClure W. H. (1988). Effect s of rampreexposure and ram breed on fertility of ewes in summer breeding. Journal of Animal Science. 66:1622-1626.

23. Ozyurtlu N, Kucukaslan I, Cetin Y. (2010). Characterization of oestrous induction response, oestrous duration, fecundity and fertility in awassi ewes during the non-breeding season utilizing both CIDR and intravaginal sponge treatments. Reprod Domest Anim. 45:464e7.

24. Pearce DT, Oldham CM. (1983). 'Ram effect' in the breeding season. Proc Aust Soc Reprod Biol. 15:49.

25. Shinomiya A, Shimmura T, Nishiwaki-Ohkawa T, Yoshimura T. (2014). Regulation of seasonal reproduction by hypothalamic activation of thyroid hormone. Front Endocrinol. 5:12.

26. Talebkhan Garoussi, M. and Golzar. E., (2005). Pregnancy rate improvement in subfertille dairy cattle by Norgestomet and Oestradiol Valerate. Reproduction in Domestic Animals, 40, 346.

27. Ungerfeld R, Rubianes E, (1999). Effectiveness of short-term progestogen primings for the induction of fertile oestrus with eCG in ewes during late seasonal anoestrus. Animal Science. 68, 349-353. 
28. Ungerfeld R., Suarez G., Carbajal B., Silva L., Laca R., Forsberg M. and Rubianes E. (2003). Medroxyprogesterone priming and response to the ram effect in Corriedale ewes during the non-breeding season. Theriogenology. 60 , $35-45$.

29. Vinoles C, Forsberg M, Banchero G, Rubianes E. (2001). Effect of long-term and short-term progestagen treatment on follicular development and pregnancy rate in cyclic ewes. Theriogenology. 55:993-1004.

30. Windorski EJ, Schauer CS, Wurst AK, Inskeep EK, Luther JS. (2008). Effects of melengestrol

31. acetate and P.G. 600 on fertility in rambouillet ewes outside the natural breeding season. Theriogenology. 70:227e32.

32. Youngquist, R.S., Threlfall, W. R. (2007). Current therapy in large animal. Theriogenology 2. W. B. Saunders Company, USA. P. 706-710.

\section{Figures}

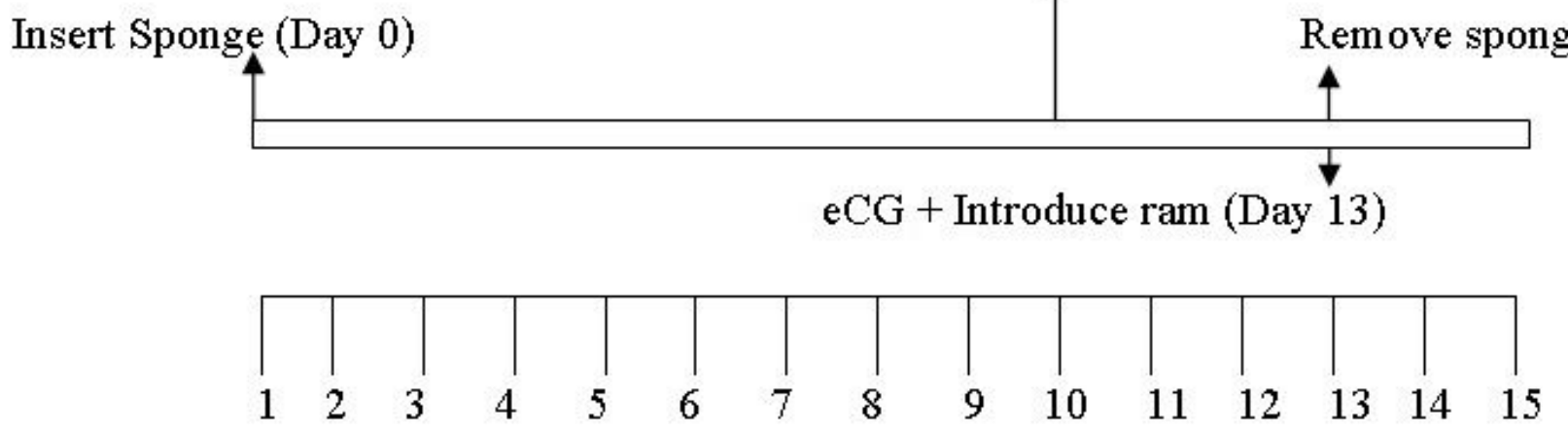

\section{Figure 1}

Protocol used for oestrus-synchronization in the anoestrous ewes during the non-breeding season using progestagen (MAP) intravaginal sponge, ram exposure with or without eCG. 